\title{
UNIVERSITYOF
}

FORWARD

THINKING

WESTMINSTER用

WestminsterResearch

http://www.westminster.ac.uk/westminsterresearch

Georg Lukács as a Communications Scholar: Cultural and Digital

Labour in the Context of Lukács' Ontology of Social Being

Fuchs, Christian

This is an author-formatted, electronic version of an article published in Media, Culture \& Society, first published on December 23, 2015 doi:10.1177/0163443715613637

The definitive version is available online at:

http://dx.doi.org/10.1177/0163443715613637

(c) Sage Publications 2015.

The WestminsterResearch online digital archive at the University of Westminster aims to make the research output of the University available to a wider audience. Copyright and Moral Rights remain with the authors and/or copyright owners.

Whilst further distribution of specific materials from within this archive is forbidden, you may freely distribute the URL of WestminsterResearch: ((http://westminsterresearch.wmin.ac.uk/).

In case of abuse or copyright appearing without permission e-mail repository@westminster.ac.uk 
Fuchs, Christian. 2015. Georg Lukács as a Communications Scholar: Cultural and Digital Labour in the Context of Lukács' Ontology of Social Being. In Media, Culture \& Society, first published on December 23, 2015 as doi:10.1177/0163443715613637

\author{
<1:>Georg Lukács as a Communications Scholar: Cultural and Digital Labour \\ in the Context of Lukács' Ontology of Social Being \\ Christian Fuchs \\ University of Westminster, UK
}

\begin{abstract}
The task of this work is to apply thoughts from Georg Lukács' final book, the Ontology of Social Being, for the theoretical analysis of cultural and digital labour. It discusses Lukács' concepts of work and communication and relates them to the analysis of cultural and digital work. It also analyses his conception of the relation of labour and ideology and points out how we can make use of it for critically understanding social media ideologies. Lukács opposes the dualist separation of the realms of work and ideas. He introduces in this context the notion of teleological positing that allows us to better understand cultural and digital labour as well as associated ideologies, such as the engaging/connecting/sharing-ideology, today. The analysis shows that Lukács' Ontology is in the age of Facebook, YouTube, and Twitter still a very relevant book, although it has thus far not received the attention that it deserves. This article also introduces the Ontology's main ideas on work and culture, which is important because large parts of the book have not been translated from the German original into English. Lukács' notion of teleological positing is crucial for understanding the common features of the economy and culture.
\end{abstract}

Keywords: Georg Lukács, Ontology of Social Being, work, labour, culture, communication, ideology, cultural work, digital labour, engaging/connecting/sharing ideology, Internet, social media

\title{
Corresponding author:
}

Christian Fuchs, Communication and Media Research Institute, University of Westminster, Watford Road, Northwick Park, HA1 3TP, UK Email: c.fuchs@westminster.ac.uk,@fuchschristian

Christian Fuchs is professor at the University of Westminster's Communication and Media Research Institute. He is editor of the journal tripleC: Communication, Capitalism \& Critique and author of books such as Culture and Economy in the Age of Social Media and Digital Labour and Karl Marx.

\section{$<2:>1$. Introduction}

The task of this work is to apply thoughts from Georg Lukács' final book, the Ontology of Social Being, for the analysis of cultural and digital labour. Section 2 discusses Lukács' concept of work and communication and relates them to the analysis of cultural and digital work. Section 3 focuses on his analysis of labour and ideology and points out how we can make use of it for the critical understanding of social media ideologies. Section 4 draws some conclusions. This article also introduces the Ontology's main ideas on work and culture, which is important because 
large parts of the book have not been translated from the German original into English.

Georg Lukács was one of the $20^{\text {th }}$ century's most well known Marxist philosophers. His book History and Class Consciousnes: Studies in Marxist Dialectics (Lukács, 1923/1971) is among the most influential studies of the proletariat and reified consciousness. History and Class Consciousness focuses on the analysis of class-consciousness, ideology, and reification. Labour is a strongly subordinated and rather neglected topic in the book. Language and communication play almost no role in it. In a preface written for the new 1967 edition, Lukács (1923/1971: xvii) acknowledges the neglect of labour in the book: 'It is true that the attempt is made to explain all ideological phenomena by reference to their basis in economics but, despite this, the purview of economics is narrowed down because its basic Marxist category, labour as the mediator of the metabolic interaction between society and nature, is missing'.

The Ontology in contrast is a theory of society and capitalism and is therefore much more concerned with the relationship between work and culture as well as that between labour and ideology. It also gives attention to communication and language, which makes it particularly interesting for reflections from a media and communications perspective. In the reception of Lukács' works, there has been a very strong focus on History and Class Consciousness, overlooking that he also wrote other important works, such as the Ontology of Social Being. This also becomes evident in more recent publications on Lukács.

Andrew Feenberg (2014: viii) argues in his book The Philosophy of Praxis: Marx, Lukács and the Frankfurt School that History and Class Consciousness is the 'pivotal text of [the] philosophy of praxis'. He therefore focuses the entire book on this work and its relevance and does not mention the Ontology once. The book Georg Lukács: The Fundamental Dissonance of Existence (Bewes and Hall, 2011) is a collection of 13 essays. They contain just one reference to the Ontology and 127 to History and Class Consciousness. The collected volume Georg Lukács Reconsidered (Thompson, 2011) consists of 13 essays. They in total make 13 references to the Ontology and contain hundreds of references to and quotes from History and Class Consciousness. Chris Nineham's (2010) Capitalism and Class Consciousness: The Ideas of Georg Lukács focuses on History and Class Consciousness and does not mention the Ontology.

In the first volume of Theory of Communicative Action, Jürgen Habermas (1984) devotes chapter IV to the topic From Lukács to Adorno: Rationalization as Reification. He shows the influence that Lukács had on the Frankfurt School and focuses his analysis <3:> on Lukács' concept of reification in History and Class Consciousness. Habermas argues that Horkheimer and Adorno's 'critique of instrumental reason understands itself as a critique of reification that takes up Lukacs' Weber reception without accepting the implications of his objectivistic philosophy of history' (Habermas, 1984: 366). Habermas' criticised that Horkheimer and Adorno lack a theory of communicative rationality that negates instrumental rationality. In formulating this critique however, because of his pure focus on History and Class Consciousness and his neglect of the Ontology of Social Being, Habermas does not realise that the importance of communication in society can be grounded in Lukács' works itself, which may be a better way for a critical theory than using concepts of communication that stem from bourgeois approaches such as John L. Austin and John Searle's speech act theories and George Herbert Mead's symbolic interactionism. 
The Ontology was written in the years 1964-1970 and was Lukács' final work (Fehér et al., 1976). In his study of the Ontology, Nicolas Tertulian argues that Lukács' aim in this work was 'to reconstruct ontology as the fundamental discipline of philosophical reflexion' (Tertulian, 1988: 247) and to work out 'a really universal theory of the categories of existence' (249). It is an extensive book comprising of 1460 pages in total, separated into two volumes in the German edition (Lukács 1986a, 1986b).. Some chapters of the Ontology have been translated into English and published in three parts on a total of 436 pages, which shows that large parts have remained thus far untranslated. The first part of the English edition focuses on Hegel (Lukács, 1978a), the second on Marx (Lukács, 1978b), and the third on labour (Lukács, 1978c). The second German volume (Lukács, 1986b) contains a part called Das Ideelle und die Ideologie (The Realm of Ideas and Ideology) that consists of three parts: Das Ideelle in der Ökonomie (The Role of the Ideal in the Economy), Zur Ontologie des ideellen Moments (Toward an Ontology of the Ideal Moment), and Das Problem der Ideologie (The Problem of Ideology). It also contains a section on work that has been translated (Lukács, 1978c). Given that there is both a focus on work and ideas in one volume, it is clear that the Ontology promises insights into the relationship of the economy and culture.

Lukács' doctoral students Ferenc Fehér, Ágnes Heller, György Markus, and Mihály Vajda (1976) published their notes on the Ontology, in which they formulated dissatisfaction with the work concerning concepts such as nature, objectification, reflection, value, freedom, and progress. They also note that it remained an unfinished work because Lukács, who only partly agreed with his students' criticisms, died before he could carry out planned revisions. But overall, he was not convinced by his students' remarks. Rather 'at the end of his life, Lukács was persuaded that it was in his Ontology that he had furnished the essential and definitive form of his thought' (Tertulian, 1988: 248).

The analysis shows that the Ontology is largely ignored and has not been discussed. For a cultural-materialist perspective on society however, the work promises insights into the relationship of work on the one hand and communication and language on the other hand, as becomes evident when for example Titus Stahl (2013) in an encyclopaedia entry about Lukács writes about the Ontology: 'From these ontological commitments, it follows that the existence of the social totality depends on the intentionality which guides individual acts of labor and vice versa [...] Lukács therefore $<\mathbf{4}$ : $>$ describes social phenomena - as language and institutions - as modifications and 'mediations' of the relations of the labor process. That is, they are media of 'indirect' teleological positing because they enable forms of action which do not directly modify nature, but which indirectly aspire to bring other persons to do so'. Language and communication in the Ontology are explained as part of the dialectics of society, in which work undergoes dialectical mediations. 'The principal aim of the ontological-genetical method developed by Lukács in his last work is to show how, in beginning from the elementary act of work, social life constitutes itself as a tissue of objectifications of greater and greater complexity, as interhuman relations better and better articulated, thanks precisely to the relation of dialectical tension between the teleological-activity of individual subjects and the network of objective causal determinations' (Tertulian, 1988: 258).

\section{Work and Communication}

Lukács starts the second German volume of the Ontology with a discussion of work's 
ontology. He uses the German term Arbeit that has been translated into English as labour. The term labour goes back to the Latin word laborem that means hard work, pain, and trouble (Fuchs, 2015: 23-24). The German word Arbeit derives from the Germanic term arba, which means slave (ibid.). The English word work and the German term werken go back to the Indo-European term uerg (doing, acting) (ibid.). They have the connotative meaning of creating something that has artistic value. In contemporary language, the terms work and labour are often used interchangeably in English, and the German word Arbeit often stands for both work and labour. It is certainly not Lukács' intention to assume that slavery and toil are features of all societies. In the discussion that follows, I therefore replace his usage of the term labour by 'work' where he speaks of anthropological features of the economy in society.

Lukács defines work as 'a relationship of interchange between man (society) and nature, and moreover with inorganic nature (tools, raw materials, object of labour) as well as organic' (1978c: iv) and 'the positing of a goal and its means' (22), 'the metabolism between man (society) and nature' that is an "'eternal" form that persists through the change in social formations' (39). Work 'involves a process between human activity and nature: its acts are directed towards the transformation of natural objects into use-values' (47). It is the 'intervention into concrete causal relations in order to bring about the realization of the goal' (67).

Work is a 'teleological positing' that results in 'the rise of a new objectivity' (3). Work is teleological because in it, a 'conscious creator' (human beings) produces with a purpose, orientation and goal (5). So the human teleology that Lukács considers as being characteristic for work and therefore for society is not opposed to causality and is not an external, esoteric force that drives society to a higher goal (such as Hegel's Weltgeist or in pre-Socratic Greek philosophy Anaxagoras' nous), but is immanent in society itself, namely in human practice and consciousness.

Lukács' (1978c) examples are predominantly taken from agriculture and hunting. When describing concrete work processes, he speaks for instance of the selection of 'one <5:> stone out of a heap of stones' as tool (31), of hunting (47), or the human use of fire (Lukács, 1986b: 34). In a materialist philosophy, there is nothing outside of matter and therefore nothing outside of nature. Humans and society are however different from non-human beings in that they can make conscious choices between alternatives and anticipate the potential effects of their behaviour, which enables morality. Work not only takes physical objects found in nature as its input, but also physical and non-physical objects created by humans. The tools of work are not just physical tools, but can also be information-processing technologies such as the computer. The products of work processes are not just physical goods, but also information, non-physical services, and social relations. With the development of scientific and technological progress, human work therefore has the tendency to distance itself from its close grounding in natural objects. One may therefore say that work is not just a process between humans and nature, but one between humans, nature and culture, in which humans create with the help of technologies physical, social, and informational use-values out of natural, industrial, and cultural objects.

Lukács (1978c) was aware of this circumstance and therefore argued: 'In the later and more developed forms of social practice, the effect on other people comes more to the fore, and ultimately - if only ultimately - this effect aims at the production of use-values' (47). Work's teleological positing has historically become more distanced from nature and has become 'also designed to cause other men to carry out positings of this kind in their turn' (128). This results in 'man's own behaviour, his own 
subjectivity, becoming the object of a teleological positing' (128). 'The decisive variations arise by the object and medium of realization in the teleological positings becoming ever more social. This does not mean, as we know, that the natural basis disappears, simply that the exclusive orientation to nature that characterizes work as we originally presupposed it is replaced by intentions that are objectively mixed in character, and become ever more strongly social' (129).

Lukács here argues that the social itself, such as relations, intentions, experiences and knowledge, in the course of society's development has become more part of the objects, tools and products of work so that work has partly been distanced from its original natural basis, which however does not mean that information work substitutes, but rather complements agricultural, extractive and industrial work. Lukács distinguishes between two types of teleological positings: those that change nature and those that change the social (Lukács, 1986b: 136). The second would become the more important, the more work and co-operation develop (ibid.). They are expressions of 'mental work' (ibid.).

Society is for Lukács a totality consisting of over-grasping moments, i.e. systems that reach over into each other. It is a 'complex of complexes' (Lukács, 1986b: 155; see also 181) that help reproducing society (182). Language is one of these complexes. It is a subjective organ and objective medium that enables social reproduction so that the human species can continuously preserve itself by continuous change of subjective and objective moments (169). Language use and communication are for Lukács constitutive moments in the social reproduction of society. He does however, unlike Niklas <6:> Luhmann (1995), not assume that communication is a subject in itself that continuously produces further communications in an autopoietic manner, so that social systems and society in a self-referential manner reproduce themselves (see Fuchs, 2008: chapter 3). The problem of Luhmann's approach is that he considers, in a functionalist manner, humans as outside observers of social systems, as sensors in the environment of social systems (Luhmann, 1995: 410). For Lukács, communication as a form of social reproduction in contrast depends on active human, social, languaging beings inside the systems that they reproduce through interaction with nature and interaction between themselves.

Consciousness plays a crucial role in the 'active and productive being of the positing of causal relationships' (Lukács, 1978c: 31). That work is a conscious activity means that workers constantly make choices between behaviour alternatives, which results in a 'chain of causality' that in contrast to nature is not automatic, but consciously decided (33). The work process is 'a chain of alternatives' (33). If a programmer for example codes a piece of software, $\mathrm{s} /$ he must consciously decide which algorithm is used next, how it is implemented, which syntax elements are used, etc. in order to achieve the goal that the programme should fulfil. Consciousness enables 'human self-control' (45), 'self-realization', 'self-founded being', and 'social being' (46).

Lukács (1986b: 478) argues that dualist consciousness and theories that draw a sharp distinction between the physical and the ideational reflect in an ideological manner society's division of labour that has, since the emergence of slavery, instituted this division in the economy itself. One should however not forget that a similar separation is also immanent in patriarchy that institutes a gendered division between physical and social labour as well as in gerontocracy that is based on a generational division between labour and collective decision-making. Lukács opposes dualist ontologies of society with a dialectical ontology. 
For Lukács (1978c), work is the essential and foundational activity of humans and society that is the ground of other phenomena such as language (v). It is the 'model for all social practice, all active social behaviour' (46). Work 'is the underlying and hence the simplest and most elementary form of those complexes whose dynamic interaction is what constitutes the specificity of social practice' (59). There is an 'identity of identity and non-identity' of work and other forms of human practice (59).

Lukács considers teleological positing (the conscious and active production of changes by realising subjective intentions in the objective world) as a common feature of work and communication, i.e. the economy and culture. There is an 'ontological similarity of base and superstructure as they are both based on teleological positings and their causal effects ${ }^{2}$ (Lukács, 1986b: 424). In the economy, where work creates goods, the intentional goals tend to be much more clearly defined, whereas in culture, where communication influences social behaviour, there is much more scope for what is considered desirable and undesirable, for 'reactions to societal matters of fact, situations, tasks, etc. ${ }^{3}$ (Lukács 1986b: 417). Lukács says that in the economy, the value of a product depends on whether it is 'immediately useful or non-useful, whereas in artistic creation the field and possibilities of value and non-value are extraordinarily widely stretched and hardly determinable in advance ${ }^{44}(535)$.

Teleological positing means that ideas are a guiding and goal-setting dimension of work so that culture is immanent in work itself. The human brain defines goals that are $<7$ : $>$ conditioned by economic and social needs and for realising them guides human activities. Culture however is not the same as the economy, but is a guiding feature of the economy that created by work goes beyond the economy and takes effect in the form of collective meanings all over society. Culture is simultaneously economic and non-economic.

Lukács says that ideology is not the same as cultural work, but can emanate from it. In making this argument, he argues for a true dialectic of the culture and economy: he on the one hand sees all culture and ideology produced by work, i.e. there is an economic foundation of cultural work. Culture and ideology also take on an emergent quality that goes beyond the economy so that the meanings cultural work produces take effect all over society. This explains why Lukács speaks of the identity and nonidentity of work and culture. 'Mental work is, also as a moment of society's division of labour, by no means identical to ideology. Their connection is therefore very deep: The result of any mental work can turn into ideology in certain social situations, society's division of labour constantly creates situations in which such turns become necessary and permanent ${ }^{5}$ (Lukács, 1986b: 427).

For Lukács, consciousness is not reality, but a form of objectivity that reproduces reality (1978c: 26). 'Ontologically, social being divides into two heterogeneous moments, [...] being and its reflection in consciousness' (26). Human consciousness was 'called into being in work, for work, and by work' (52). There is no photographic copying of reality in consciousness, but reflection is 'conditioned by the posited goals' and 'the social reproduction of life, originally by work' (27). Consciousness and work have at the same time a relationship of 'linkage and autonomy' (52). So consciousness alone is not behaviour and work, but a foundation of both. Consciousness has an important role in society because it 'sets goals', masters the human body, and allows a 'distanced and critical' relationship of the person to him/herself and to others (109). 'And the origin of this mastery lies undoubtedly in work' (109).

All work and action has an aspect of consciousness because before working and action, humans reflect what they want to achieve and how. Ideas and material changes 
of the world are therefore not independent, but inherently connected (Lukács, 1986b: 297). Lukács criticises that theorists such as Georgi Plechanov, Karl Kautsky, Max Adler, and Stalin have separated the economy from the world of ideas in a dualist manner (298-99). He in this discussion points to the fact that human thought is not work itself, but one of its necessary preconditions and parts. Reflection precedes and enables both physical work that creates physical goods and mental work that creates informational use-values in society.

Lukács argues that communication already exists in higher animals for the purposes of 'danger, food, sexual desire, etc.' (1978c: 100). Human language and communication would arise out of economic necessity when humans are required to say something to each other in order to master the rising complexity of the organisation of production. So for example hunting requires co-operation because it is a complex process, for which co-ordination is necessary. 'Its [co-operation's] mere existence, albeit on a low level, results in the emergence of another key determination of social being from work, the precise communication of humans united in work: language' ${ }^{6}$ (Lukács, 1986b, 118). Language enables teleological positings that have the intention to "encourage other $<\mathbf{8}$ : $>$ people to conduct a teleological positing that is desired by the predicating subject" ${ }^{7}$ (Lukács, 1986b: 119). Language develops with the development of work, co-operation, and the division of work (119).

Communication is based on the fact that the human is an 'answering being, 8 (Lukács, 1986b: 339). An answer, however, presupposes a question. Humans have the capacity to find answers posed by nature and to ask questions about nature, themselves, and society. We can therefore say in expanding Lukács' thought that communication is based on a dialectic of questioning and answering, in which a question produces answers, which produces further questions, and so on.

Words that form a language are abstractions and generalisations of reality (Lukács, 1986b: 346, 419). The description of a specific circumstance is concrete and therefore requires a complex linguistic combination of words (1986b: 346). Language enables the 'distancing of the object from the subject' (1978c: 100) and enables this distancing. 'In this way what is depicted by the verbal sign is separated from the objects it describes, and hence also from the subject uttering it, becoming the mental expression for an entire group of particular phenomena, so that it can be applied in a similar way in completely different contexts and by completely different subjects' (100). Human language allows the repetition and development of production processes in the same or different spaces at different times. Lukács at a high level of theoretical abstraction hints at the fact that the development of production technologies allows the spatio-temporal distancing of production, the development of transport and distribution technologies enables the spatio-temporal distancing of distribution, and the development of conservation and preservation technologies fosters the distancing of consumption. 'In its further development, work constantly interposes whole series of mediations between man and the immediate goal which he is ultimately concerned to achieve. In this way, work gives rise to a differentiation between immediate and more mediated goal positings' (101-102).

The spatio-temporal distancing of production requires physical and linguistic technologies of production, distribution, and consumption. Communication is an important means of organising work and human activity in space-time and over spatio-temporal distances. 'The mental distancing of objects by language only makes the real distancing that thus arises communicable, making possible its establishment as the common possession of a society' (102). The storage of information enables the organisation of the economy and society over spatio-temporal distances and across 
generations. Society's development is therefore connected to the development of information technologies that store and distribute information about human social relations. They include for example human memory, tradition, myths, art, writing, lists, timetables, the book, libraries, archives, schools, universities, newspapers, the telegraph, the telephone, the radio, the television, cinema, the database, computers, computer-mediated communication, the Internet, records, tapes, CDs, DVDs, Blu-ray discs, digital hard disks, servers, FTP, cloud storage, etc. (see Fuchs, 2003).

$<9:>$

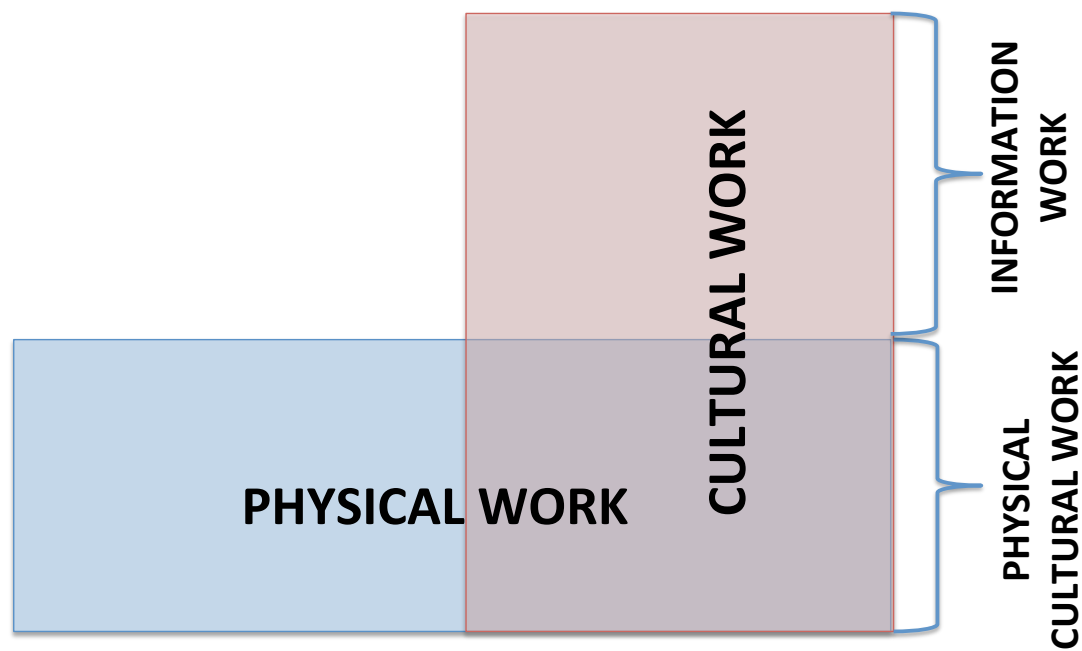

Figure 1: A dialectical model of cultural work

Language is a complex in society that mediates both the human metabolism with nature as well as the relations between humans in society (Lukács, 1986b: 18). It helps distancing human subjects from objects and from other subjects and at the same time helps to co-ordinate the production of new objects out of existing objects and the emergence and reproduction of social relations between humans.

For Lukács, consciousness enables a form of freedom within necessity (Lukács 1986b: 308), i.e. human choices between different actions based on conditions that are not self-chosen. Conscious human action opens up the world to chance and makes it to a certain degree undetermined and shapeable by humans. To illustrate this circumstance, Lukács (1986b: 304) quotes in this context Marx (1867: 208-9): 'No one can sell unless someone else purchases. But no one directly needs to purchase because he has just sold'. If someone who has money chooses to buy or to save, what exactly s/he buys in the case of a purchase, and from whom, is not determined, but rather depends on an interaction of complex conditions and choices, the 'mutual dialectical polarity of the ideal and the real' ${ }^{9}$ (Lukács, 1986b: 306). Market supply, local accessibility, wages and prices, class struggles, transport structures, etc. condition the possible choices that the potential purchaser makes based on his/her evaluation of these structures. The ideal moves the real, but it can only move 'real possibilities of being-in-itself ${ }^{10}$ (343).

Based on Lukács' idea that mental work creates culture that is simultaneously economic and transcends the economy, we can design a dialectical model of cultural work (see figure 1). 
Using a stage model allows us to identify and relate different levels of cultural work (see figure 1). Cultural work is a term that encompasses organisational levels of work that are simultaneously distinct and dialectically connected: cultural work has an emergent quality, namely information work that creates content and is based on and grounded in physical cultural work, which creates information technologies through extractive and industrial work processes. Physical work takes place inside and outside of culture: it creates information technologies and its components (cultural physical work) as well as other products (non-cultural physical work) that do not primarily have symbolic functions in society (such as cars, toothbrushes or cups). Cars, toothbrushes, or cups do not $<\mathbf{1 0}$ : $>$ primarily have the role of informing others or enabling communication with others, but rather help humans achieve the tasks of transport, cleanliness, and nutrition. Culture and information work however feed back on these products and create symbolic meanings used in contemporary society by companies for marketing them. Cultural work is a unity of physical cultural work and information work that interact with each other, are connected and at the same time distinct.

All culture involves cultural work and effects of cultural products in society (meaning-making). The production and communication of meanings, social norms and morals are work processes: they create cultural use-values. Culture requires on the one hand human creativity for creating cultural content and on the other hand specific forms and media for storage and communication. The creation of information and communication through language is specific for work conducted in the cultural system: informational and communication work. For having social effects in society, humans with the help of information and communication technologies, such as computers, TV, radio, newspapers, books, recorded films, recorded music, language, etc., organise (i.e. store, process, transport, analyse, transform, create) information and communication. Physical cultural work produces information technologies. Culture encompasses a) physical cultural work that creates cultural technologies (information and communication technologies) and b) information work that creates information and communication.

The term digital labour emerged for understanding value-creation on social media platforms such as Facebook, YouTube, Twitter and Weibo (see the contributions in Scholz, 2013). It would however be idealist to limit the notion of digital labour to the exploitation of users' online activities by commercial platforms that use targeted advertising or to the creation of digital content that is sold as a commodity. The creation of digital content requires a technological infrastructure that is produced and maintained by labour processes (Fuchs, 2014, 2015). Digital labour is all paid and unpaid labour that helps creating digital technologies, content, and data that is sold as a commodity. It includes diverse activities such as slave-labour extracting minerals that form the physical foundation of information technologies, the labour of militarily controlled and highly exploited hardware assemblers who work under conditions of Taylorist industrialism, a highly paid knowledge labour aristocracy, precarious digital service workers as well as imperialistically exploited knowledge workers in developing countries, workers conducting the industrial recycling and management of e-waste, or highly hazardous informal physical e-waste labour (Fuchs, 2014, 2015). Such forms of digital labour form an international division of digital labour that creates the digital media industry's profits (ibid.). Why is it important to have such a unified concept of digital labour? Nick Dyer-Witheford (2014: 175) provides an answer: 'To name the global worker is to make a map; and a map is also a weapon'. 
Digital work is a specific organisational form of cultural work that creates digital media, content, or data (see figure 2).

$<11:>$

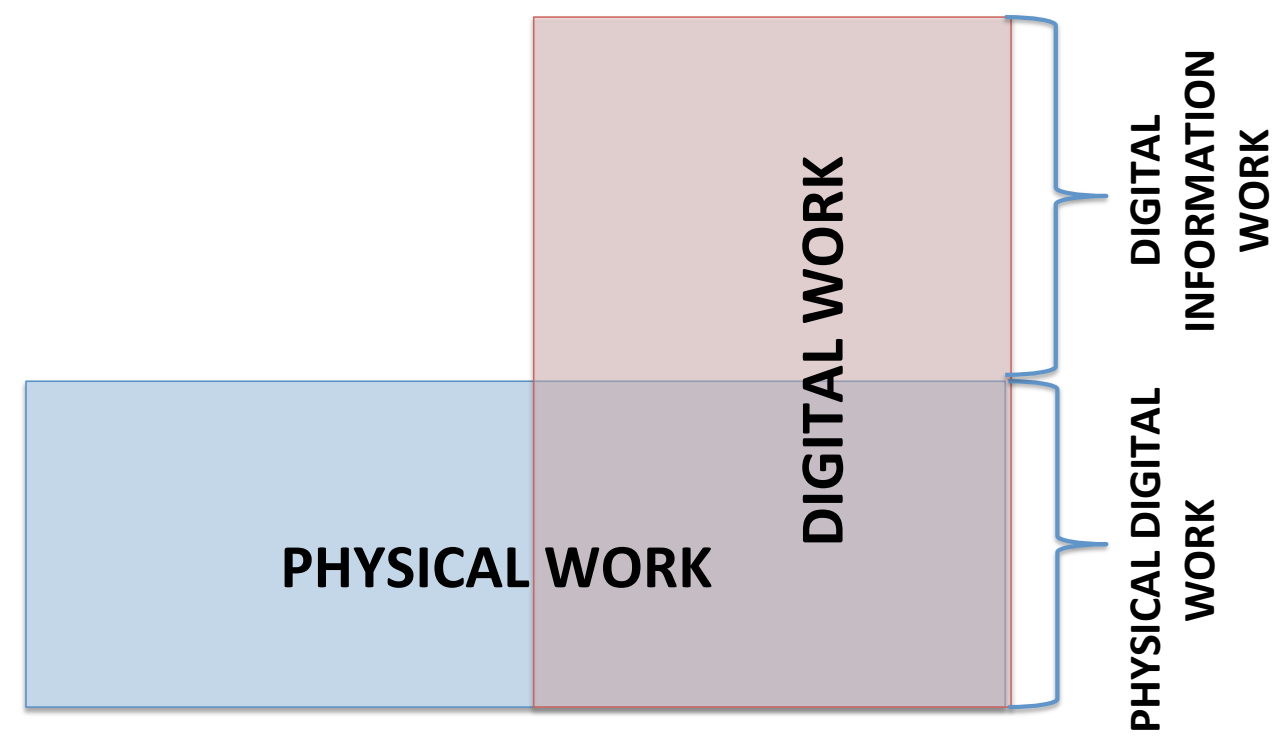

Figure 2: A dialectical model of digital work

Digital labour is alienated digital work: it is alienated from itself, from the instruments and objects of labour and from the products of labour. Digital labour is digital work that is organised within class relations. Figure 3 shows a model of the international division of digital labour. Each production step involves human subjects (S) using technologies/instruments of labour $(\mathrm{T})$ on objects of labour $(\mathrm{O})$ so that a product emerges.

DIGITAL LABOUR

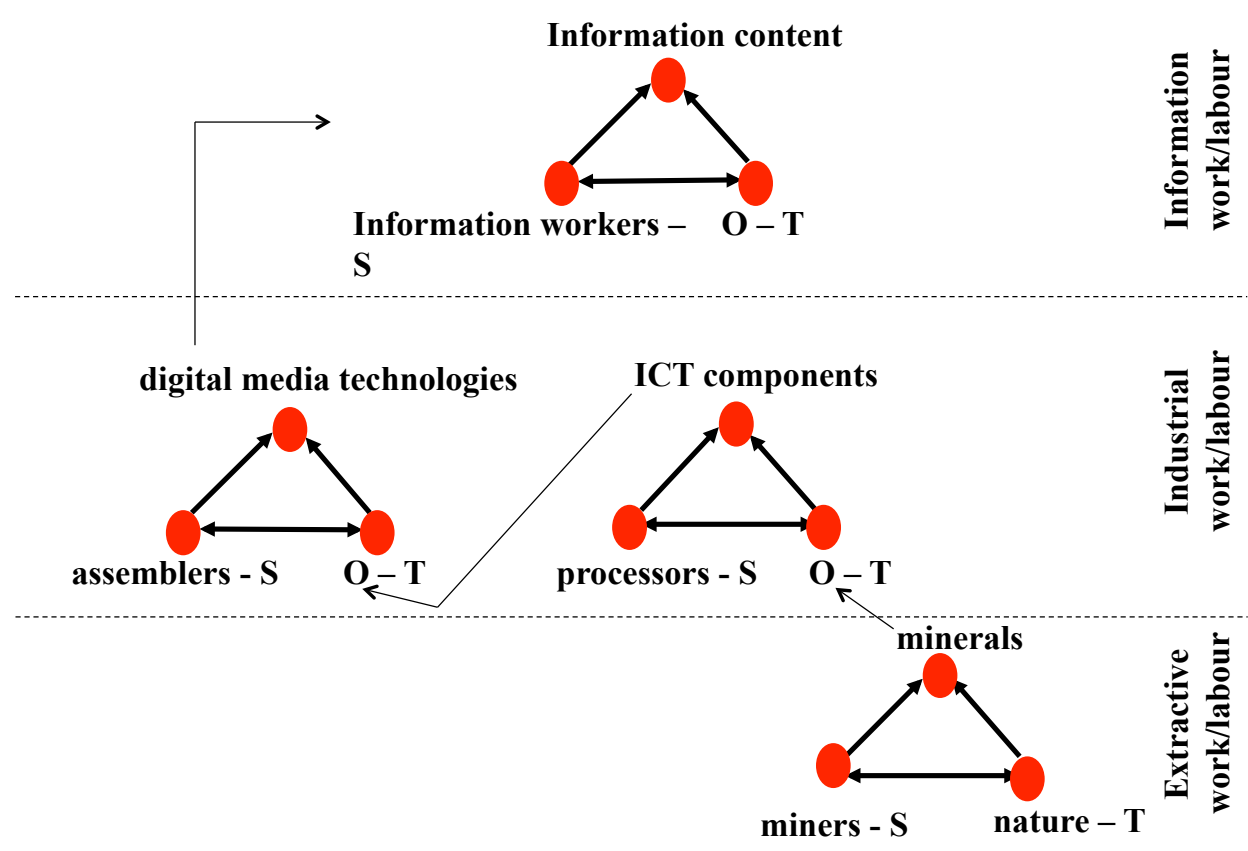

Figure 3: The international division of digital labour 
Physical digital labour creates minerals and ICT components that are assembled into digital media technologies. It involves extractive and industrial digital labour. Digital information workers use this technological infrastructure in order to create digital contents and data that are sold as commodities. Physical and informational digital work can take place within various social relations of production, including slavery, freelance labour, wage labour, feminised labour, unpaid labour, etc. In the case that these relations are class relations, we speak of digital labour. In contrast, if we have to do with commons-based relations of production, in which there are no class relations but common <12:> property and common production, we merely speak of digital work. Digital work is a more general term than digital labour. All digital labour is digital work, but not all digital work is digital labour. Table 1 shows an overview of relations of production into which digital work can be embedded. It is based on a distinction between different forms of ownership (self-control, partly self-control and partly alien control, full alien control)

\begin{tabular}{|l|l|l|l|}
\hline & $\begin{array}{l}\text { Owner of labour } \\
\text { power }\end{array}$ & $\begin{array}{l}\text { Owner of the } \\
\text { means of } \\
\text { production }\end{array}$ & $\begin{array}{l}\text { Owner of the } \\
\text { products of work }\end{array}$ \\
\hline Patriarchy & Patriarch & Patriarch & Family \\
\hline Slavery & Slave master & Slave master & Slave master \\
\hline Feudalism & $\begin{array}{l}\text { Partly self-control, } \\
\text { partly lord }\end{array}$ & $\begin{array}{l}\text { Partly self-control, } \\
\text { partly lord }\end{array}$ & $\begin{array}{l}\text { Partly self-control, } \\
\text { partly lord }\end{array}$ \\
\hline Capitalism & Worker & Capitalist & Capitalist \\
\hline Communism & Self & All & $\begin{array}{l}\text { Partly all, partly } \\
\text { individual }\end{array}$ \\
\hline
\end{tabular}

Table 1: The main forms of the relations of production in various modes of production

Lukács' Ontology is a general theory of society that draws attention to the importance of work, language, and communication in general. However, it is also an ontology of class society, in which he analyses the role of labour and ideology.

\section{Labour and Ideology}

We have seen in the previous section that for Lukács, cultural workers create culture, which means that also ideologies are created by labour, namely ideological labour. Lukács makes clear that not every cultural work creates ideology, but cultural products can turn into ideology if they serve dominative interests in class societies. Critiques of ideology such as Critical Discourse Analysis, often with the help of text and visual analysis, focus on uncovering the structure of ideologies, but neglect the working conditions under concrete humans and organisations create ideologies, whereas labour studies often focus on the study of working conditions and neglect how ideologies frame labour and capital (see: Fuchs, 2015: chapter 3). Lukács' approach allows us to understand that labour and ideology are inherently connected: There is ideology-producing and -communicating labour - ideological labour - just like there are ideologies of and about labour.

Lukács (1978c) argues that use-value can exist independently from exchange-value as 'a product of work which man is able to make use of in the reproduction of his existence' (v). With the rise of capitalism, use-value has however become the 
antagonist of exchange-value. 'The more general the exchange-value, the clearer and more precisely socially necessary labour time comes into the limelight as the economic foundation of its respective quantity ${ }^{11}$ (Lukács, 1986b: 124). Lukács says that 'the division of labour mediated and brought about by exchange-value produces the principle of control by time by a better subjective use of it' (1978c: 83).

Exchange-value is a contradictory form that in capitalism 'assumes the leading role in human social intercourse' and therefore $<\mathbf{1 3}$ : $>$ subsumes use-value, but at the same time 'can only come to prevail by being based on use-value' (87).

Lukács (1986b: 635) argues that for Marx, reification and the alienation of humans and capitalist labour that results from it are connected to labour-time. Humans are reduced to a cog in the accumulation process that aims at creating as much profit per unit of time as possible: 'Time is everything, man is nothing; he is, at the most, time's carcase. Quality no longer matters. Quantity alone decides everything; hour for hour, day for day' (Marx, 1847: 127). The modern form of instrumental reason has its origin in the logic of quantification and the reduction of humans to instruments for quantitative increases of the ruling and owning elites' power. The psychological reasons why humans reproduce ideologies would have to do with fear and hope (Lukács, 1986b: 643).

Lukács connects the existence of ideologies as cultural phenomena to the existence of alienated labour in the economy. The reification of labour power necessitates ideologies that justify the existence of alienation. Ideologies attempt to alienate the human mind. They try to instrumentalise consciousness in the interest of dominant powers. Lukács (1986b: 397) is sceptical of Gramsci's theory of ideology, in which ideologies are understood as individual worldviews. For Lukács, ideology in capitalism has its foundation in the masking of the subject by the object, for example the masking of surplus value produced in social relations as an expenditure of a specific amount of labour-time by monetary profit (Lukács, 1986b: 319-21). Ideology is made up of thoughts, practices, ideas, words, concepts, phrases, sentences, texts, belief systems, meanings, representations, artefacts, institutions, systems or combinations thereof that represent and justify one group's or individual's domination and power by misrepresenting, one-dimensionally presenting or distorting reality in symbolic representations. (Fuchs 2015: chapter 3).

Ideology exists for Lukács (1986b) only where there are social struggles, i.e. in societies with antagonistic interests (398). They are "theoretical or practical vehicles for fighting out societal conflicts" ${ }^{12}$ (400). Ideology presupposes 'societal structures, in which different groups and conflicting interests act and strive to impose their interest onto the totality of society as its general interest. To put it shortly: The emergence and diffusion of ideologies appears as the general characteristic of class societies ${ }^{13}$ (Lukács, 1986b: 405).

Lukács (1986b: 581) points out that commodity fetishism contains elements of religious ideology/alienation: Money and commodities appear as quasi-Gods. Religion is sublated in capitalist ideology. Religion is for Lukács the archetype of all ideological alienation (605). Lukács argues that the ontology of everyday life is the 'all-sided medium of immediacy' ${ }^{14}$ (556) that connects ideologies to the objective world of phenomena. In everyday life communication, humans get in touch with culture and ideologies.

Lukács says that ideology has in capitalism since the rise of mass consumption in the $20^{\text {th }}$ century taken on a transition from the power of not-having to the power of having: 'In workers' everyday life, the power of having does not appear as simple privation, as influence of not-having as the most important means for the necessary 
everyday satisfaction of needs on regular life, but in contrast as the power of direct having, as the race <14: $>$ with other humans and groups in the attempt to raise personal prestige by the quantity and quality of having, ${ }^{15}$ (Lukács, 1986b: 699). Advertising plays a crucial role in this process:

The effect on humans is primarily oriented on the belief that the purchase of particular hair tonics, ties, cigarettes, cars, etc., the visit to specific holiday resorts etc. results in one's personality being truly acknowledged in one's environment. The promotion of commodities as originally in ad promotion is not primary here, but rather the consumer's personal prestige that shall be attained by purchasing. Underlying is a double tendency: on the one hand the intention to influence humans into a specific direction and to form them, on the other hand the intention to breed the particularity of humans, to enforce their perception that this superficial differentiation of particularity that has been purchased on the world market is the sole way of how humans become personalities, i.e. how they can achieve personal recognition ${ }^{16}(701)$.

If we look at today's media landscape, we can see that advertising plays a very important role in it (McKinsey, 2014). Lukács' analysis that in the $20^{\text {th }}$ century advertising has become one of the dominant forms of ideology in capitalism is even more true in the $21^{\text {st }}$ century. On the World Wide Web, targeted advertising is the dominant capital accumulation model (Fuchs, 2014, 2015). Its introduction in the first decade of the $21^{\text {st }}$ century has been accompanied by new ideologies that try to justify and legitimate capitalist Internet platforms.

Internet companies are a first kind of actor that spread Internet ideologies. Here are some examples:

- Facebook says it provides 'the power to share and to make the world more open and connected ${ }^{, 17}$.

- YouTube conceives the essence of freedom as the possibility 'to connect, inform and inspire others across the globe and acts as a distribution platform for original content creators and advertisers large and small, ${ }^{18}$.

- For Twitter, the freedom of social media is 'to connect with people, express yourself and discover what's happening' and 'give everyone the power to create and share ideas and information instantly, ${ }^{19}$.

- Instagram says it is a 'fast, beautiful and fun way to share your life with friends and family 20 .

- tumblr argues it enables you to 'share the things you love"21.

- Sina Weibo's self-understanding ${ }^{22}$ is that it is a platform designed to 'allow users to connect and share information anywhere, anytime and with anyone on our platform' and provides 'an array of online media and social networking services to our users to create a rich canvas for businesses and brand advertisers to connect and engage with their targeted audiences'.

Not only do social media platforms' marketing and PR departments advance the idea that social media is great because it allows engaging, connecting, and sharing (Fuchs, 2015), but also some journalists and many consultants communicate such ideologies. They have business opportunities and capital accumulation in mind whenever they think of the Internet and are a second type of actor producing social media ideologies. Kevin Kelly (2009) for example argued in Wired magazine <15:> that social media enables sharing, cooperation, collaboration, and collectivism. He celebrates 'the 
power of sharing, cooperation, collaboration, openness, free pricing, and transparency'. Marketing guru Gary Vaynerchuk (2011) writes that social media enables the emergence of a thank you economy, in which entrepreneurs create 'a culture of caring' (233), empower 'people to be forthright, creative, and generous', and allow 'customers to help you shape your brand or business' (233). Also celebratory cultural studies scholars have used similar language for the analysis of social media. Such scholars form a third type of ideologues producing social media ideologies. Henry Jenkins writes for example that 'the Web has become a site of consumer participation' (Jenkins, 2008: 137).

Lukács has based his theory of ideology as reification on Marx's concept of commodity fetishism, in which an object or something concrete (such as the commodity or money) masks the subject, the abstract, and social relations (for a detailed discussion of commodity fetishism from a media and communication studies perspective, see Fuchs 2016, chapter 1). The engaging/connecting/sharing-ideology is a special form of a reifying ideology, a form of inverted commodity fetishism: The users do not immediately experience the commodity on commercial social media as it is not immediately visible and experienced when logging into platforms without payment. This is different from buying a cinema, concert or circus ticket, where money directly mediates cultural experience. The commodification of data happens behind the users' back. The social use-value of social media is immediately experienced and masks the commodity form. On targeted-advertising funded 'free' use platforms, the subject and the social masks the object and the commodity form. Inverted commodity fetishism conditions the emergence of the engaging/connecting/sharing ideology that in a populist manner appeals to users' direct social experience and fetishises the social in order to mask the reality of commodification. The engaging/connecting/sharing ideology foregrounds and constantly stresses categories of non-instrumental, social, communicative reason such as caring, sharing, emotions, empowering, creativity, connecting, or making. This social dimension of online media in the contemporary capitalist Internet however serves instrumental reason, namely the accumulation of capital. The universe of usevalue and sociality has in the engaging/connecting/sharing ideology become subsumed under the logic of instrumental and technological reason that fosters capital accumulation in the interest of a particularistic capitalist class interest.

How do users react to the engaging/connecting/sharing ideology? There are different possible responses of audiences, users, consumers, and citizens to ideologies. They can accept, resist, or partly accept and partly resist ideologies. This was the point of Stuart Hall's (1973) encoding/decoding model. The problem of this model is that in a relativist manner, it conveys the impression that all three options are equally likely. The likelihood of specific audience responses is complex, having to do with factors such as time, education, skills, personal experiences, political worldviews, etc. In a capitalist society, audience responses therefore tend to be asymmetrically distributed.

Empirical studies indicate that users do not simply reproduce the engaging/connecting/sharing ideology, but rather seem to be at the same time supportive of corporate social media's social use-value dimension and sceptical of its exchange-value dimension and the commodification of personal data (Allmer et al., 2014). They tend to have little knowledge about how the political economy of social media works and providing them with such information seems to empower them in being able to feel competent to make <16:> political and moral assessments of social 
media (ibid.). Internet users' opinions towards social media are quite ambivalent and not automatically ideological.

One important implication of Lukács' Ontology is that ideologies are not freefloating, independent structures, but are produced under specific working conditions by an ideological labour force. Concrete human beings and organisations create and reproduce the engaging/connecting/sharing ideology.

B.J. Mendelson argues in his book Social Media is Bullshit that myths about the Internet that he based on what Harry G. Frankfurt (2005) calls 'bullshit' spread through an 'asshole-based economy' (Mendelson, 2012: 54) that cyber hipster, tech media and marketers, analysts, corporations, mainstream media and users advance (74). Mendelson draws on his own long experience as Internet consultant and concludes that you can only attain a lot of attention and visibility on social media if you are a powerful organisation investing a lot of money. He argues that advertising consultants tend to create the impression that social media is a great business opportunity for everyone in order to foster their own profit interests by selling the engaging/connecting/sharing ideology. Social media's ideological workers include tech companies' strategists, marketing gurus and consultants, neoliberal journalists, and users who reproduce this ideology as hegemony.

\section{Conclusion}

For Lukács, work understood as the active, conscious teleological positing of changes so that use-values are created in order to achieve goals is the foundation of humans and society. He opposes the dualist separation of the realms of work and ideas. Teleological positing - the conscious and active production of changes by realising subjective intentions in the objective world - is the common feature of the economy and culture. Teleological positing means that ideas are a guiding and goal-setting dimension of work so that culture is immanent in work itself. Lukács argues that mental work creates and communicates ideas as social use-values and is therefore a specific form of teleological positing.

Lukács' dialectical ontology of society can inspire us to think about the relationship between culture and economy. It provides an ontological foundation for conceiving cultural work as consisting of physical and informational cultural work that form a dialectic. Digital work is then a specific form of cultural work that creates digital media technologies, digital content, or digital data. It consists of physical and informational digital work that are interconnected and organised in the form of various social relations. In contemporary global capitalism, digital work takes on the form of an international division of digital labour.

For Lukács, a specific form of cultural work - ideological labour - creates ideologies. In ideology, an object masks a subject. It is concrete humans and groups in specific labour processes and under particular working conditions, who produce and communicate ideologies. With the rise of advertising-financed social media platforms, a new form of ideology has emerged that justifies the capitalist Internet by foregrounding the social-use value these media enable in order to mask the commodification of data and the logic of capital accumulation.

For Lukács, class struggle is an essential implication of Marxist theory that aims at overcoming alienation and reification. He argues with Marx that alienation can <17: $>$ only be abolished through social struggles, which includes ideological struggles (1986b: 653). Alienation can 'only be sublated by a fundamental economic-politicalsocial revolution of the whole system as general and objective mass phenomenon, ${ }^{23}$ 
(698). The bottom line of the political economy of the contemporary landscape of cultural and digital labour is that we need political struggles for an alternative Internet and media that are re-designed within an alternative political and societal framework.

\footnotetext{
${ }^{1}$ Translation from German: ,geistige[n] Arbeit'

${ }^{2}$ Translation from German: ,ontologischen Gleichartigkeit von Basis und Überbau, daß sie nämlich beide auf teleologischen Setzungen und deren kausalen Folgen beruhen'.

${ }^{3}$ Translation from German: ,Spielraum gewünschter (oder unerwünschter) Reaktionen auf gesellschaftliche Tatbestände, Situationen, Aufgaben etc.'

${ }^{4}$ Translation from German: ,daß auf je einer konkreten Produktionsstufe der Wert des Produkts der Arbeit sich scharf danach scheidet, ob es unmittelbar brauchbar oder unbrauchbar ist, während im künstlerischen Schaffen das Feld, die Möglichkeit von Wert oder Unwert außerordentlich weit gestreckt, im voraus kaum bestimmbar ist'.

${ }^{5}$ Translation from German: ,geistige Arbeit ist, auch als Moment der gesellschaftlichen Arbeitsteilung, keineswegs mit Ideologie identisch. Ihre Verknüpftheit ist aber eben deshalb sehr innig: das Ergebnis jeder geistigen Arbeit kann in bestimmten sozialen Situationen in Ideologie umschlagen, ja die gesellschaftliche Arbeitsteilung bringt ununterbrochen Situationen hervor, in denen dieses Umschlagen notwendig und permanent wird'.

${ }^{6}$ Translation from German: ,Ihre bloße Existenz, wenn auch auf noch so niedrigem Niveau, läßt eine weitere entscheidende Bestimmung des gesellschaftlichen Seins aus der Arbeit herauswachsen, die präzise Kommunikation zwischen den zu einer Arbeit vereinten Menschen: die Sprache'.

${ }^{7}$ Translation from German: ,die Intention haben, andere Menschen dazu zu veranlassen, eine vom Subjekt der Aussage gewünschte teleologische Setzung ihrerseits zu vollziehen'.

${ }^{8}$ Translation from German: ,ein antwortendes Wesen'

${ }^{9}$ Translation from German: ,wechselseitigen dialektischen Polarität des Ideellen und des Reellen'.

${ }^{10}$ Translation from German: ,realen Möglichkeiten im Ansichseienden'.

${ }^{11}$ Translation from German: ,Je allgemeiner sich der Tauschwert verbreitet, desto deutlicher und bestimmter tritt als die ökonomische Fundierung seiner jeweiligen Größe die gesellschaftlich notwendige Arbeitszeit in den Mittelpunkt'.

${ }^{12}$ Translation from German: ,theoretisches oder praktisches Vehikel zum Ausfechten gesellschaftlicher Konflikte'.

<18:>

${ }^{13}$ Translation from German: ,Die Hauptfrage ist demnach, daß das Entstehen solcher Ideologien Gesellschaftsstrukturen voraussetzt, in denen verschiedene Gruppen und entgegengesetzte Interessen wirken und bestrebt sind, diese der Gesamtgesellschaft als deren allgemeines Interesse aufzudrängen. Kurz gefaßt: Entstehen und Verbreitung von Ideologien erscheint als das allgemeine Kennzeichen der Klassengesellschaften'.

${ }^{14}$ Translation from German: ,,allseitige Medium der Unmittelbarkeit'

${ }^{15}$ Translation from German: ,Im Alltagsleben des Arbeiters zeigt sich die Macht des Habens nicht mehr als ein einfaches Entbehren, als Einfluß des Nichthabens der wichtigsten Mittel zur alltäglich notwendigen Bedürfnisbefriedigung auf das normale Leben, sondern im Gegenteil als die des direkten Habens, als der Wettlauf mit anderen Menschen und Gruppen im Versuch, die persönliche Geltung durch Quantität und Qualität des Habens zu erhöhen'.

${ }^{16}$ Translation from German: ,Die Wirkung auf den Menschen richtet sich also primär darauf, daß er des Glaubens sei, durch Erwerb der betreffenden Haarwässer, Krawatten, Zigaretten, Autos etc., durch Besuch bestimmter Badeorte etc. als echte, von seiner Umgebung anerkannte Persönlichkeit zu gelten. Nicht das Anpreisen der Waren ist also hier das Primäre, wie ursprünglich im annoncierenden Anpreisen, sondern das persönliche Prestige, das durch ihre Erwerbung für den Käufer erreicht werden soll. Dem liegt sozial gesehen eine Doppeltendenz zugrunde: einerseits die Absicht, die Menschen in bestimmter Richtung zu beeinflussen, zu formen (wieder sei an Hitlers These über den femininen Charakter der Massen erinnert), andererseits die, die Partikularität der Menschen hochzuzüchten, in ihnen die Einbildung zu verstärken, gerade diese auf dem Warenmarkt erworbene oberflächliche Differenzierung der Partikularität sei der alleinige Weg des Menschen, Persönlichkeit zu werden, d. h. persönliches Ansehen zu erringen'.

${ }^{17} \mathrm{https}$ ://www.facebook.com/FacebookUK/info, accessed on April 10, 2014.

18 http://www.youtube.com/yt/about/en-GB/, accessed on April 10, 2014.
} 
${ }^{19} \mathrm{https} / / /$ about.twitter.com/company, accessed on April 10, 2014.

${ }^{20} \mathrm{http}$ ://instagram.com, accessed on April 10, 2014.

21 https://www.tumblr.com/, accessed on April 10, 2014.

$22 \mathrm{http}$ ://corp.sina.com.cn/eng/sina intr eng.htm, accessed on April 9, 2014.

${ }^{23}$ Translation from German: ,kann diese Entfremdung nur durch eine fundamentale ökonomischpolitisch-soziale Umwälzung des ganzen Systems als allgemeine und objektive Massenerscheinung aufgehoben werden'.

\section{References}

Allmer T, Fuchs C, Kreilinger C and Sevignani S (2014) Social networking sites in the surveillance society: Critical perspectives and empirical findings. In Jansson A and Christensen M (eds) Media, Surveillance and Identity. Social Perspectives. New York: Peter Lang, pp. 49-70.

Bewes T and Hall T (eds) (2011) Georg Lukács: The Fundamental Dissonance of Existence. London: Continuum International.

Dyer-Witheford N (2014) The global worker and the digital front. In: Fuchs C and Sandoval M (eds) Critique, Social Media and the Information Society. New York: Routledge, pp. 165-178.

$<19:>$

Feenberg A (2014) The Philosophy of Praxis. Marx, Lukács and the Frankfurt School. London: Verso.

Fehér F, Heller Á, Markus G and Vajda M (1976) Notes on Lukács'ontology. Telos 29: $160-181$.

Frankfurt HG (2005) On Bullshit. Princeton, NJ: Princeton University Press.

Fuchs C (2003) Structuration theory and self-organization. Systemic Practice and Action Research 16(2): 133-167.

Fuchs C (2008) Internet and Society. Social Theory in the Information Age. New York: Routledge.

Fuchs C (2014) Digital Labour and Karl Marx. New York: Routledge.

Fuchs C (2015) Culture and Economy in the Age of Social Media. New York: Routledge.

Fuchs C (2016) Reading Marx in the Information Age: A Media and Communication Studies Perspective on "Capital Volume 1". New York: Routledge.

Habermas J (1984) The Theory of Communicative Action. Volume 1: Reason and the Rationalization of Society. Boston, MA: Beacon Press.

Hall S (1973) Encoding and decoding in the television discourse. Centre for Contemporary Cultural Studies Occasional Papers \#7. Available at: http://www.birmingham.ac.uk/Documents/college-artslaw/history/cccs/stencilledoccasional-papers/1to8and11 to24and38to48/SOP07.pdf

Jenkins H (2008) Convergence Culture. New York: New York University Press.

Kelly K (2009) The new socialism: Global collectivist society is coming online. Wired Online, May 22, 2009. Available at: http://archive.wired.com/culture/culturereviews/magazine/1706/nep newsocialism? currentPage $=$ all

Luhmann N (1995) Social Systems. Stanford, CA: Stanford University Press. Lukács G (1923/1971) History and Class Consciousness. Studies in Marxist Dialectics. Cambridge, MA: The MIT Press.

Lukács G (1978a) The Ontology of Social Being. 1: Hegel. London: Merlin. Lukács G (1978b) The Ontology of Social Being. 2: Marx. London: Merlin. 
Lukács G (1978c) The Ontology of Social Being. 3: Labour. London: Merlin.

Lukács G (1986a) Zur Ontologie des gesellschaftlichen Seins. Erster Halbband Bände. Georg Lukács Werke, Band 13. Darmstadt: Luchterhand.

Lukács G (1986b) Zur Ontologie des gesellschaftlichen Seins. Zweiter Halbband Bände. Georg Lukács Werke, Band 14. Darmstadt: Luchterhand.

Marx K (1847) The poverty of philosophy. In: $M E C W$, Volume 6. New York: International Publishers, pp. 105-212.

Marx K (1867) Capital. Volume 1. London: Penguin.

McKinsey (2014) McKinsey Global Media Report 2014. Available at: http://www.mckinsey.com/ /media/mckinsey/dotcom/client_service/media\%20and $\% 20$ entertainment $/ \mathrm{pdfs} / 6232 \% 20$ global media trends\%20report 2014 industry \%20overview_v8 online.ashx.

Mendelson BJ (2012) Social media is Bullshit. New York: St. Martin's Press.

Nineham C (2010) Capitalism and Class Consciousness. The Ideas of Georg Lukács. London: Counterfire.

Scholz T (ed) (2013) Digital Labor. The Internet as Playground and Factory. New York: Routledge.

Stahl T (2013) Georg Lukács. In: Stanford Encyclopedia of Philosophy. Available at: http://plato.stanford.edu/entries/lukacs/\#Ont

Tertulian N (1988) Lukács' Ontology. In: Rockmore T (ed) Lukács Today: Essays in Marxist Philosophy. Dordrecht: Reidel, pp. 243-273.

Thompson MJ (ed) (2011) Georg Lukács Reconsidered. London: Continuum International.

Vaynerchuck G (2011) The Thank You Economy. New York: Harper Business. 